УДК 004:005.336.2:37.091.12.011.3-051

Карташова Любов Андріївна

доктор педагогічних наук, професор, професор

Комунальний навчальний заклад Київської обласної ради

«Київський обласний інститут післядипломної освіти педагогічних кадрів»,

Генеральний директор ТОВ «Акцент», м. Київ, Україна

lkartashova@ua.fm

Бахмат Наталія Валеріївна

доктор педагогічних наук, доцент, професор кафедри теорії та методик початкової освіти

Кам'янець-Подільський національний університет імені Івана Огієнка,

м. Кам'янець-Подільський, Україна

bahger.teacher@gmail.com

Пліш Ірина Валеріївна

кандидат педагогічних наук, директор

Спеціалізована школа-дитсадок «Лісова казка» 3 поглибленим вивченням іноземних мов,

м. Київ, Україна

apogey95@ukr.net

\title{
РОЗВИТОК ЦИФРОВОЇ КОМПЕТЕНТНОСТІ ПЕДАГОГА В ІНФОРМАЦИЙНО- ОСВІТНЬОМУ СЕРЕДОВИЩІ ЗАКЛАДУ ЗАГАЛЬНОЇ СЕРЕДНЬОЇ ОСВІТИ
}

\begin{abstract}
Анотація. Інформатизація системи освіти спричиняє активне використання інформаційнокомунікаційних технологій (IКТ) суб'єктами освітнього процесу, що позитивно позначається на його ефективності й сприяє формуванню професійних компетентностей педагогів. У роботі виокремлюється один із складників професійної компетентності, цифрова компетентність - якість педагога, яка означає здатність та вміння систематичного, логічного та системного використання IКТ, вказує на його сучасність, мобільність та конкурентоздатність. Незважаючи на різноманітність рішень для її розвитку, система освіти Нової української школи потребує пошуку нових шляхів у цьому напрямі. Одним з них $є$ розроблення інноваційного електронного освітнього ресурсу - електронної платформи mobiSchool, що є адаптованою до умов неперервної інформатизації освіти та містить webінструментарій для проектування та формування автентичних електронних середовищ (webпрототипів) закладів освіти. Експериментальне впровадження mobiSchool вказує на позитивні результати в неперервному підвищенні та розвитку цифрових компетентностей педагогів. В основу розробки закладено принципи доступності, зрозумілості, особистісної спрямованості, формування мотивації та зацікавленості. Зазначений ресурс відмінний від подібних тим, що: він $є$ кросплатформенним та не потребує придбання додаткового обладнання; користувачі забезпечуються тьюторським супроводом; для роботи користувачам достатньо отримати від розробника вхідні дані; користувачі отримують різні рівні доступу (адміністратора, вчителя, учня, батьків); він $є$ адаптивним - для кожного закладу освіти розробляється його унікальний web-прототип; об'єднує та реалізує всі функції освітнього процесу - навчальну, розвиваючу, виховну, стимулюючу (мотиваційну) й організаційну (управлінську); може бути використаний за всіх форм навчання.
\end{abstract}

Ключові слова: електронний освітній ресурс; інформаційно-освітнє електронне середовище; Нова українська школа; електронна платформа mobiSchool; електронний навчальний кабінет; дистанційне навчання.

\section{1. ВСТУП}

Постановка проблеми. Перспективи розвитку освіти України та об'єктивна реальність сучасного світу вказують на актуальність оновлення системи освіти в цілому та педагогічних технологій і підходів формування цифрової компетентності педагогів зокрема. Апріорі розвиток системи освіти, iï структура та компоненти повинні 
відповідати науковим, технологічним і соціальним цілям та напрямам розвитку як суспільства, так і інформатизації. Об'єктивні, суспільно зумовлені, процеси переходу до інформаційного суспільства вимагають упровадження інноваційних підходів викладання й навчання, які забезпечать конкурентоспроможність громадян України. Тобто значимим компонентом інформатизації суспільства є інформатизація освіти «процес, спрямований на задоволення освітніх інформаційних потреб (організаційних, економічних, наукових, технічних, виробничих, управлінських i навчальнометодичних) учасників освітнього процесу» [6]. Останніми роками в Україні вже зроблено важливі кроки в напрямі впровадження інформаційно-комунікаційних технологій (IКТ) в освітній процес шляхом: забезпечення закладів освіти персональними комп'ютерами, підключення до Інтернету, розроблення електронних освітніх ресурсів, що, в цілому, має спрямованість на формування нового позитивного ставлення педагогів до застосування IКТ та, як наслідок, підвищення та розвитку їхніх цифрових компетентностей.

Аналіз останніх досліджень і публікацій. Поява електронних освітніх ресурсів (ЕОР) як складників ІКТ забезпечує доступність знань, розвиток інтелектуальних i творчих здібностей учнів на основі особистісно зорієнтованого підходу, інтенсифікації освітнього процесу тощо. Накопичений у процесі інформатизації освіти практичний досвід і результати спеціальних педагогічних досліджень показують, що використання IКТ в освіті позитивно позначається на ефективності освітнього процесу на всіх його рівнях. 3 іншої боку, оскільки освіті відводиться випереджальна роль у формуванні компетентностей особистості [10], так само неодмінним чинником ефективності цього процесу слід розглядати ІКТ як креативний засіб, що в останні роки набув вагомого значення для піднесення економіки держави.

У свою чергу, з метою успішного виконання професійних функцій, педагог повинен характеризуватися певним комплексом компетентностей. Відповідно до нормативних документів, «компетентність - динамічна комбінація знань, умінь і практичних навичок, способів мислення, професійних, світоглядних і громадянських якостей, морально-етичних цінностей, які $\epsilon$ результатом навчання у вищому навчальному закладі за відповідною освітньою програмою та підставою для присвоєння кваліфікації» [10]; «компетентність - набута в процесі навчання інтегрована здатність, що складається із знань, умінь, досвіду, цінностей і ставлення, що можуть цілісно реалізовуватися на практиці» [7].

Суттєвим та неодмінним складником професійної компетентності виокремилась така якість як «компетентність у галузі інформаційних технологій». Не так давно для позначення цього явища науковцями використовувалась різноманітна термінологія, якот: «інформатична компетентність» (Ю. Дорошенко [9]), «ІТ-компетентність» (А. Гуржій, Л. Карташова, В. Лапінський [7]), «ІК-компетентність» (О. Спірін [15]), «інформаційно-цифрова компетентність» (Л. Гриневич) [8]). Проте слід зазначити, що, незалежно від формулювання, зазначену якість педагога нині відносять до ключових, надпредметних компетентностей, вона вважається необхідним, важливим складником професійної компетентності сучасного фахівця будь-якої професії та грунтується на сукупності знань, умінь і навичок у галузі ІКТ.

Останнім часом дослідники дійшли одностайності в іiі позначенні. Схильність отримав термін «цифрова компетентність», який вживається в країнах зарубіжжя Європі, США, Японії $[16 ; 17 ; 20 ; 21]$. Узагальнення термінології вказує на те, що «Цифрова компетентність - це здатність використовувати цифрові медіа й IКТ, розуміти і критично оцінювати різні аспекти цифрових медіа та медіа контенту, а також уміти ефективно комунікувати в різноманітних контекстах» [17], «якість фахівця, що вказує на рівень кваліфікації від базового візуального сприйняття та практичних 
навичок до більш критичних, оціночних та концептуальних підходів використання IКТ, а також включає в себе ставлення та поінформованість в галузі ІКТ» [21], «набір знань, умінь, ставлень (включаючи здатності, стратегії, цінності та обізнаність), що необхідні для використання IКТ та цифрових медіа 3 метою виконання завдань; вирішення проблем; спілкування; управління інформацією; співробітництва; створення і поширення змісту; та побудови знання ефективно, результативно, відповідно, критично, творчо, самостійно, гнучко, етично, рефлексивно для роботи, відпочинку, спільної діяльності, навчання, спілкування, задоволення споживчих потреб та забезпечення можливостей для реалізації прав» [20], «навички роботи в інформаційнокомунікаційному (цифровому) середовищі як провідна ознака цифрової грамотності, соціокультурна складова (нові артефакти, нові практики цифрової культури 3 відповідними ціннісними орієнтирами та особистісним досвідом)» [3].

Нам імпонує визначення терміну «цифрова компетентність», який сформульовано В. Биковим: «цифрова компетентність (ЦКом) учителя - знання, вміння та навички в галузі ІКТ та здатність їх застосування в професійній діяльності» [1; 2]. Всі попередні визначення можна узагальнити формулюванням, опублікованим Службою науки та знань Свропейської Комісії Наукового центру СС, де цифрову компетентність убачають у свідомому та критичному використанні технологій цифрового суспільства в роботі, вільному часі та спілкуванні [18].

На гостру потребу формування цієї якості педагогів неодноразово вказувала міністр МОН України Л. Гриневич [4]. 3 цією метою заплановано низку заходів, які проводяться на державному рівні:

- Затвердити орієнтовну навчальну програму підготовки тренерів для навчання педагогічних працівників, які навчатимуть учнів перших класів у 2018/2019 і 2019/2020 навчальних роках [14].

- Збільшили час на проходження підвищення кваліфікації: в інститутах післядипломної освіти та самостійний вибір вчителем інших форм підвищення кваліфікації [4].

- Створити Національну освітню онлайн-платформу 3 інтерактивними навчальними матеріалами для школярів, навчальними матеріалами для вчителів (методичні матеріали, відеоуроки, рекомендації тощо), порадами для батьків із питань їхнього спілкування зі школою. У перспективі вбачається можливість використання цієї платформи не лише школярами та вчителями в навчальному процесі, а й усіма громадянами України для самоосвіти [4; 5].

- Розробити грунтовну національну політику «цифровізації» освіти як пріоритетної компоненти реформи освіти в цілому [14].

Однак спостерігається недостатній рівень ЦКом педагогів - на це вказують як українські, так і зарубіжні дослідники Д. Белшоу, В. Биков, Д. Галкін, Б. Гірш, Г. Крибер, М. Лещенко, Р. Мартін, Л. Манович, П. Матюшко, О. Овчарук, В. Ребрина, Дж. Стоммел та ін. Зазначений гандж, зокрема, розкривається як у процесі підготовки до професійної діяльності (наприклад, розроблення навчально-методичних матеріалів), так і в процесі самоосвіти, а також у готовності використовувати IКТ безпосередньо в освітньому процесі. Причинами такого факту, по-перше, можна вважати відсутність мотивації, досвіду, вмінь і навичок фаховоспрямованого застосування IКТ; відсутність відповідного рівня ІКТ-готовності як складника професійної готовності; по-друге, зазначені якості свого часу були сформовані в процесі навчання в закладах вищої освіти, однак їх рівень не відповідає реальним потребам і вимогам освітнього процесу.

За авторським баченням, відсутні інноваційні підходи неперервного розвитку ЦКом як якості, яка, апріорі, не може бути сталою одиницею - явище «інформатизація суспільства», похідною якої є ЦКом, неодмінно вказує на іiі динамічну сутність. 
Мета статті. Пошук та реалізація інноваційних підходів розв'язання проблеми формування та розвитку цифрової компетентності педагога в електронному середовищі закладу освіти.

\section{2. РЕЗУЛЬТАТИ ДОСЛІДЖЕННЯ}

У цілому ЦКом педагога передбачає його здатність та вміння систематичного, логічного та системного використання IКТ, що розкриває доступ до застосування та, можливо, і розроблення сучасних педагогічних технологій. Завдяки резервам, які забезпечуються впровадженням ІКТ в освітній процес, система освіти змінює авторитарну педагогіку гуманістичною, де створюються можливості для врахування й розвитку особливостей кожного педагога як особистості зі своїми індивідуальними потребами й якостями. Такі підходи в педагогіці забезпечують педагогам право на самобутність, унікальність та мобільність.

Утім запровадження сучасних IКT має бути виваженими, доцільними та підпорядкованими меті i змісту освітнього процесу. Одним із креативних заохочувальних засобів формування мотивації до оволодіння сучасними знаннями та отримання відповідних навичок як чинників розвитку ЦКом педагогів убачається створення інформаційно-освітнього електронного середовища (е-середовища) закладу. Таке середовище, найімовірніше, слід розглядати як електронний прототип (епрототип) закладу. В його умовах для педагогів необхідно популяризувати раціональне використання ЕОР на заняттях і в позаурочній діяльності, впровадження елементів дистанційного навчання тощо. Теоретичну основу оновлення систем освіти в цілому та розроблення е-прототипу закладу повинні скласти ідеї доступності та неперервності якісної освіти. Зазначене можна обгрунтувати:

- першочерговістю гуманістичності педагогічних технологій;

- спрямованістю на особистісні якості та можливості кожного;

- значимістю людського фактору;

- інтелектуалізацією й інтеграцією професійної діяльності людей;

- демографічними змінами тощо.

Описані явища актуалізували завдання докорінної реорганізації традиційної освітньої системи. Головна ідея полягає в створенні такої моделі освіти, яка забезпечить кожній людині можливість отримання та поповнення знань, розвиток, удосконалення, самореалізацію впродовж усього життя.

Слід пригадати, що фундаментальна роль у популяризації ідей неперервної освіти як основоположного принципу організації системи освіти належить ЮНЕСКО. Всі документи ЮНЕСКО настійливо стверджують, що кожна особа повинна отримати можливість неперервно продовжувати навчання [9]. В останні роки неперервність у системі освіти пропонується в якості ключового принципу концепції освітньої політики розвинених країн. Звісно, що досить складний і довготерміновий процес побудови неперервності системи освіти в кожній країні набуває характерологічних рис відповідно до економічного рівня, інформатизації та автентичності розвитку.

Одним із основних напрямів реформування освіти відповідно до Концепції «Нова українська школа» (НУШ) $є$ «наскрізне застосування інформаційних технологій в освітньому процесі та управлінні закладами освіти і системою освіти» [12], який «має стати інструментом забезпечення успіху Нової школи». Формування ЦКом передбачає «впевнене, а водночас, критичне застосування IКТ для створення, пошуку, обробки, обміну інформацією на роботі, в публічному просторі та приватному спілкуванні».

Найбільш загальні принципи побудови системи доступної освіти НУШ єдині і 
вони сформовані умовами глобалізації, інформатизації та потребами технічно розвинутого суспільства. А саме: зорієнтованість на особистість - потреби, якості характеру тощо; доступність та відкритість для всіх i кожного; гнучкість; різноманітність освітніх послуг; інтеграція формальних та неформальних видів освіти; створення єдиного електронного освітнього простору; широке використання IКТ.

Незважаючи на різноманітність термінів, що характеризують модель освіти відповідно до НУШ, яка відповідає сучасним і майбутнім вимогам (подальша, продовжена, неперервна, довічна освіта), вони відображають загальну сутність система навчання кожного закладу освіти (3О) повинна бути цілісною і неперервною, підпорядкованою потребам особистості кожного педагога та учня. Описані явища актуалізували завдання та напрями реорганізації традиційної освітньої системи. Головна ідея полягала у створенні автентичних умов навчання в будь-якому окремому 30, які забезпечуватимуть кожному учаснику освітнього процесу перспективи отримання та поповнення знань, розвитку та вдосконалення і самореалізацію впродовж усього життя.

Керуючись зазначеним вище, українськими науковцями розроблено та впроваджено електронну (web-) платформу mobiSchool як web-iнструментарій, який може бути застосований у формуванні зазначених вище умов навчання, а саме - у створенні електронного освітнього ресурсу (ЕОР) - web-прототипу ЗО. Щонайперше, ідеєю авторської розробки стало: 1) спрямування на організацію та підтримку всіх функцій освітнього процесу: навчальної, розвиваючої, виховної, стимулюючої (мотиваційної) і організаційної (управлінської); 2) використання його за всіх форм навчання [13].

Замислом започаткованого стало рішення проблем: а) організації та підтримки неперервності й доступності навчання у 3О, незалежно від подій, які цьому заважають; б) забезпечення кожного громадянина України доступом до якісного навчання; в) неперервний розвиток та підвищення рівня ЦКом педагогів. Платформа mobiSchool відрізняється від більшості відомих систем управління навчанням, до яких можна ії віднести, тим, що забезпечує одночасне й узгоджене функціонування всіх зазначених нижче складників розробленого ЕОР:

- електронного кабінету управління;

- електронних навчальних кабінетів - е-НК (WEB-room);

- електронних кабінетів учнів/батьків;

- web-бібліотеки, що містить адаптований до завдань і специфіки 30, навчальнометодичний контент;

- вкладені е-середовища (класу, кафедри, об’єднання тощо) - за потреби.

Ïї особливості:

1) створений web-прототип 30 є автентичним - формується відповідно до вимог та потреб 30 (закладено «принцип лего»);

2) забезпечується е-підтримка та організація всіх форм навчання online тa offline - інституційної (очна (денна, вечірня), заочна, дистанційна, мережева); індивідуальної (екстернатна, сімейна (домашня), педагогічний патронаж, на робочому місці (на виробництві) та дуальної;

3) створення і зберігання е-портфоліо освітнього процесу 30 ;

4) створення і зберігання е-портфоліо учнів та педагогів тощо;

5) залучення до дистанційної роботи в 30 інноваційних, креативних педагогів (фахівців різних галузей), які проживають в інших населених пунктах;

6) організація та підтримка інтегрованого навчання;

7) неперервна підтримка розробниками функціювання web-прототипу;

8) кросплатформенність; 
9) не потребує придбання додаткового обладнання;

10) для навчання користуванню та завантаження контенту розробник надає послуги тьютора;

11) для роботи користувачам достатньо отримати від розробника вхідні дані;

12) користувачі отримують різні рівні доступу (адміністратора, вчителя, учня, батьків).

Одним із прикладів успішного розроблення та впровадження такого ЕОР можна вказати web-прототип навчально-виховного комплексу (НВК) «ШДС «Лісова казка» гімназія «Апогей»» - «Система дистанційного навчання гімназії «Апогей»», який розгорнуто на основі mobiSchool. Створенням упродовж кількох років «Системи дистанційного навчання гімназії «Апогей» започатковано досягнення мети формування інноваційного е-середовища як чинника неперервного розвитку ЦКом педагогів. Зазначене слугувало основою для проведення педагогічного експерименту, кінцевим результатом якого стало стійке формування ЦКом учасників освітнього процесу та організація й підтримка неперервності й доступності навчання у 3О, незалежно від подій, які цьому перешкоджають.

3 метою підготовки учасників освітнього процесу (педагогів, учнів та їхніх батьків) до діяльності в умовах розробленого е-середовища НВК «ШДС «Лісова казка»- гімназія «Апогей», розробниками неперервно проводились майстер-класи, тренінги, веб - тренінги, індивідуальні консультації та практичні заняття. Для участі в зазначених заходах учасники розподілялись за рівнями ЦКом: низький, достатній та високий.

Відповідно до цього й розроблялися програми заходів - їх зміст повною мірою враховував початковий рівень ЦКом кожного учасника. Також від розробників учасники освітнього процесу отримали дві версії методичних рекомендацій (у друкованому та цифровому форматах) - окремо для педагогів та учнів (їхніх батьків), які містять досить детальну інформацію щодо використання ресурсу.

В основу експерименту було покладено припущення, що суттєве підвищення ЦКом вчителів є можливим за умови розвитку їхньої професійної діяльності в есередовищі, засадами розроблення якого стали принципи доступності, зрозумілості, відповідності розвитку суспільства тощо.

Для підвищення рівня ЦКом учителів вбачалось належним забезпечення тісного взаємозв’язку цієї якості з їх професійними компетентностями. Організація освітньої діяльності в умовах е-середовища спрямовувалась на оптимальне розв'язання фундаментальних дидактичних задач з максимально необхідним охопленням всього кола переваг IКТ. Умови е-середовища дозволили виробити певний електронний базис супроводу неперервного динамічного формування системи знань, що $є$ основою управління та забезпечення якості освітнього процесу, розвитку пізнавальної і творчої діяльності учнів.

У проведенні експерименту було використано методи: анкетування; аналіз навчальних програм та планів підготовки педагогів з дисциплін інформатичної галузі у вищій школі, навчальних планів педагогів НВК та навчально-методичних матеріалів кафедр; аналітичний огляд методик навчання в НВК. Діагностика рівнів ЦКом здійснювалась через анкетування, тестування та усне опитування.

У цілому експеримент носив порівнювальний характер: виявлялася відмінність між рівнем ЦКом на початковому етапі (констатувальний етап), поточним рівнем контрольне оцінювання зміни рівня ЦКом (формувальний етап) та підсумковим рівнем - здійснюється в кінці експерименту (завершальний етап). Результативність перемін в рівнях ЦКом вчителів гімназії в умовах розробленого е-середовища оцінювалася за наступними основними критеріями: 
- знанням теоретичного матеріалу (використання IКТ в професійні діяльності);

- умінням розв'язувати професійні задачі в електронному форматі (е-форматі) (розроблення навчально-методичних е-засобів, завантаження в особисту ебібліотеку, їх використання в освітньому процесі; розроблення е-тестів, додавання домашніх е-завдань, наповнення е-журналу; е-спілкування 3 учнями та їхніми батьками (проведення е-зборів), проведення е-уроків тощо) ;

- умінням користуватися е-модулями «Системи дистанційного навчання гімназії «Апогей»;

- застосуванням набутих знань в умовах традиційного освітнього середовища (очна, дистанційна чи змішана форма навчання) та в умовах е-середовища.

На основі означених критеріїв було проведено оцінювання рівнів ЦКом усіх педагогів НВК за такими рівнями: початковий, достатній та високий - на описаних вище етапах експерименту. Розроблені рівні відповідали стандартам ЦКом, виробленим європейською мережею EUROPASS, де фундаментальними складниками є здатність особи: використовувати, порівнювати, класифікувати, накопичувати, відтворювати (організовувати інформаційно-комунікаційні процеси); спілкуватись, співпрацювати, ділитися інформацією, брати участь у спільнотах, використовувати ЕОР (комунікація); розробляти, форматувати та редагувати текстові, відео-, аудіофайли, застосовувати базові мови програмування, використовувати ліцензії та копірайти (створення контенту); вміти захищати інформацію, економно використовувати енергію, ідентифікувати небезпечні ЕОР, розуміти негативні та позитивні впливи IКТ, уміти уникати небезпеки в е-середовищі (безпечне користування); вміти вирішувати технічні та технологічні проблеми, використовуючи різні ЕОР, уміти оновлювати та поповнювати ЕОР (вирішення проблем) [19]. У нашому експерименті описані складники були показниками, за якими оцінювався рівень сформованості ЦКом. На Рисунку 1 продемонстровано зведені результати, які свідчать про те, що «Система дистанційного навчання гімназії «Апогей» $є$ ефективним сучасним ЕОР, що створює достатні умови неперервного формування та розвитку ЦКом педагогів.

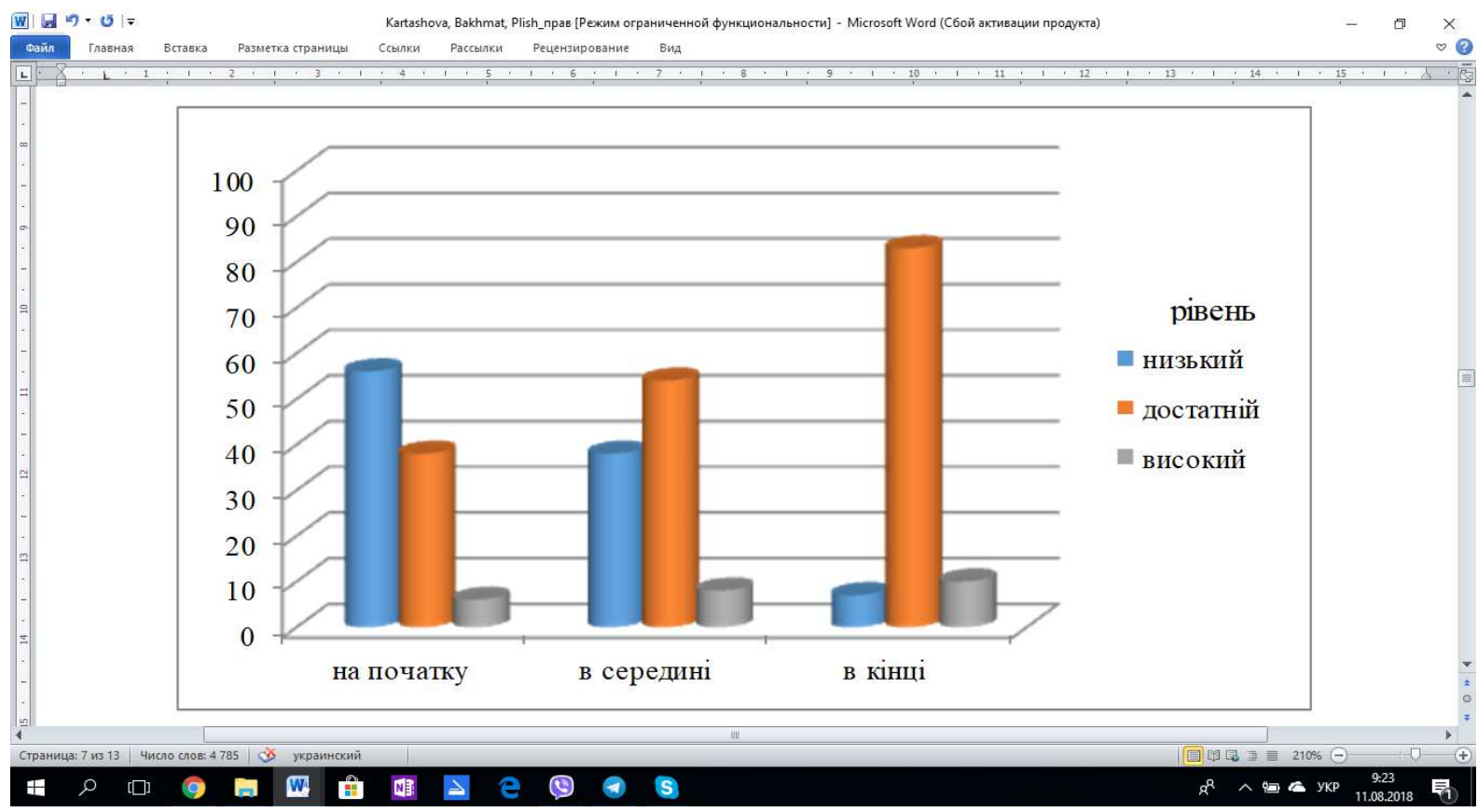

Рис. 1. Сформованість цицрової компетентності педагогів (на початку, в середині та в кіниі експерименту) (\%) 
Досвід впровадження ЕОР, розроблених на основі web-платформи mobiSchool показує, що, окрім цілей, означених вище, досягаються похідні цілі: організація та здійснення освітньої діяльності педагогів та учнів за всіх форм навчання; підвищення якості освіти; залучення діаспори до отримання української освіти; забезпечення доступності якісної освіти, зокрема особами, які: потребують інклюзивного навчання; проживають в депресивних районах; знаходяться на тимчасово окупованих територіях України, в зоні АТО; переміщені з зони АТО; а також у період карантину, пандемії, захворювань дітей на довготривалі хвороби; коли, в силу складної економічної ситуації в країні, стаються вимушені перерви в навчанні.

Результати впровадження ЕОР «Система дистанційного навчання гімназії «Апогей»», вказують на його переваги:

- доступність, зрозумілість та візуалізація інструментарію - $€$ можливість працювати користувачам 3 низьким рівнем ЦКом (3 його подальшим неперервним поступовим підвищенням);

- багатофункціональність інструментарію - можливість організовувати та здійснювати освітній процес, створювати контент,

- наявність системи управління навчанням як окремого учня, так і групи учнів - створюються умови для формування вміння здійснювати комунікацію 3 учнями, їхніми батьками та іншими педагогами;

- неперервна online та offline підтримка - проведення розробниками для педагогів консультацій, тренінгів, навчання роботи 3 контентом, навчання підтримці функціоналу та оновленню версій;

розробленням ЕОР - ці функції підтримуються розробником та здійснюється відповідна підготовка педагогів для їх реалізації.

\section{3. ВИСНОВКИ ТА ПЕРСПЕКТИВИ ПОДАЛЬШИХ ДОСЛІДЖЕНЬ}

Неперервне вдосконалення системи освіти України, перехід до Нової української школи - це чинники, які вказують на потребу нового педагогічного мислення. 3 метою задоволення умов та потреб НУШ креативними, високо інтелектуально та всебічно розвиненими педагогами здійснюються пошуки шляхів, методів та засобів розвитку зазначених якостей.

Педагоги повинні бути здатними не тільки до передавання навчального матеріалу, а й уміти організувати пізнавальну діяльність учнів, розвивати їх самостійність та творчість через використання сучасних засобів - IКТ. Саме тому постало питання неперервного підвищення їхнього рівня ЦКом - якості, сформованість якої дозволяє педагогу на високому професійному рівні використовувати ЕОР з метою пошуку, логічного відбору, систематизації, використання навчального матеріалу та організації результативного освітнього процесу.

Нині, в умовах інформатизації освіти та становлення НУШ, тільки неперервне підвищення рівня ЦКом педагогів дозволить їм оперативно та адекватно реагувати на всі змінні прогресивні умови їхньої професійної діяльності. Показниками рівнів сформованості ЦКом у проведеному експерименті стали вміння: організовувати інформаційно-комунікаційні процеси; використовувати ЕОР для комунікації; створювати контент; вирішувати проблеми використання ЕОР, уникати небезпеки в есередовищі; вирішувати технічні та технологічні проблеми, використовуючи різні ЕОР. Одним із ефективних підходів у цьому процесі вбачається організація та здійснення освітньої діяльності в е-середовищі 3О, що продемонстровано та експериментально 
підтверджено розгортанням автентичного е-середовища (web-прототипу) mobiSchool в НВК «ШДС «Лісова казка»- гімназія «Апогей»».

Окрім отриманих позитивних результатів в площині підвищення та розвитку ЦКом учасників освітнього процесу (відповідно до описаних показників), спостерігається соціальний ефект, який полягає в наступному:

- забезпечення неперервності освітнього процесу (повноформатне дистанційне навчання);

- забезпечення вільного доступу до отримання освіти всіх і кожного, також i тих, хто потребує інклюзивного навчання;

- можливість залучення до освітнього процесу закладу осіб із віддалених i депресивних районів;

- забезпечення вільного доступу до отримання освіти осібам, що проживають на неконтрольованих Україною територіях і в зоні АТО.

Напрямами подальших розвідок вбачається дослідження науково-методичних засад розвитку ЦКом педагогів з метою розроблення інтегрованих уроків та занять, а в подальшому - інтегрованих дисциплін.

\section{СПИСОК ВИКОРИСТАНИХ ДЖЕРЕЛ}

1. В. Биков, "Досвід: Цифрове навчальне середовище", Цифрова компетентність учителя. [Електронний pecypc]. Доступно: https://www.facebook.com/uesaccent/photos/pcb.1809058149395875/1809406686027688/?type=3.

2. В. Ю. Биков, "Навчальне середовище сучасних педагогічних систем", Освіта Запорізького краю. [Електронний ресурс]. Доступно: http://virtkafedra.ucoz.ua/el_gurnal /pages/vyp1/Bykov.pdf.

3. Л. Г. Гаврілова, "Цифрова культура, цифрова грамотність, цифрова компетентність як сучасні освітні феномени". [Електронний ресурс]. Доступно: https://webcache.googleusercontent.com/ search?q=cache:30SmhK8VVkQJ:https://journal.iitta.gov.ua/index.php/itlt/article/download/1744/1243+ $\& \mathrm{~cd}=3 \& \mathrm{hl}=\mathrm{ru} \& \mathrm{ct}=\mathrm{clnk} \& \mathrm{gl}=\mathrm{ua} .2$.

4. Л. Гриневич, "Від школи, де накачують знаннями, ми переходимо до школи компетентностей". [Електронний ресурс]. Доступно: https://dt.ua/EDUCATION/liliya-grinevich-perehodimo-vid-shkoli-vyakiy-tilki-napihayut-znannyami-ta-vidtvoryuyut-yih-do-shkoli-kompetentnostey-252819_.html.

5. Л. Гриневич, "Впровадження електронної освіти може зайняти $5-7$ років". [Електронний ресурс]. Доступно: https://day.kyiv.ua/uk/news/120218-vprovadzhennya-elektronnoyi-osvity-mozhe-zaynyaty-57-rokiv-grynevych.

6. Р.С. Гуревич, "Інформатизація освіти - важливий чинник розвитку суспільства XXI століття", Сучасні інформаційні технологї та інноваційні методики навчання в підготовці фахівців : методологія, теорія, досвід, проблеми : 3б. наук. пр., вип. 47, с. 5-10, 2016.

7. А. М. Гуржій та ін. ІТ-готовність вчителів іноземних мов : методологія, теорія, технології : Київ, Україна: Інститут обдарованої дитини, 2013.

8. Державний стандарт базової і повної загальної середньої освіти (2011, Лист. 23), Законодавство України. [Електронний ресурс]. Доступно: http://zakon2.rada.gov.ua/laws/show/1392-2011-\%D0\%BF.

9. Ю.О. Дорошенко та ін. "Концептуальні засади формування інформатичної компетентності майбутніх архітекторів", Інформаційно-комунікаційні технологї в сучасній освіті: досвід, проблеми, перспективи, с. 133-139, 2012.

10. Л.А. Карташова, "Віртуальна школа, електронні навчальні класи - не фантастика, а українська реальність ". [Електронний ресурс]. Доступно: http://knk.media/stati/1991-virtualna-shkolaelektronni-navchalni-klasi-ne-fantastika-a-ukrajinska-realnist.html).

11. Л.А. Карташова, "Відкритий мережевий ресурс «Асcent»: інноваційні можливості для освітян ", Комп'ютер у школі та сім’ї, №5 (133), с. 3-8, 2016.

12. Концепція нової української школи. [Електроний ресурс]. Доступно: https://mon.gov.ua/storage/app/media/zagalna\%20serednya/nova-ukrainska-shkola-compressed.pdf.

13. I. Пліш, "Дистанційне навчання в школі: використовуємо українські інновації", на ХІ Международной научной конференщии, Израиль, с. 16-19, 2016.

14. Проект Цифрова адженда України - 2020 («Цифровий порядок денний» - 2020) Концептуальні засади (версія 1.0) (2016, Груд.). [Електронний ресурс]. Доступно: https://ucci.org.ua/uploads/files/ 58e78ee3c3922.pdf. 
15. О. М. Спірін, "Інформаційно-комунікаційні та інформатичні компетентності як компоненти системи професійно-спеціалізованих компетентностей вчителя інформатики", Інформаційні технологіï $i$ засоби навчання, №5, 2009. [Електронний ресурс]. Доступно: http://www.ime.eduua.net/em13/content/09somtio.htm.

16. Ala-Mutka K., "Mapping Digital Competence: Towards a Conceptual Understanding. Luxemburg: IPTSJRC», 2011". [Електронний ресурс]. Доступно: http://ipts.jrc.ec.europa.eu/publications/pub.cfm?id=4699.

17. Carretero Gomez Stephanie, vuorikari Riina, Punie Yves. "DigComp 2.1: The Digital Competence", Framework for Citizens with eight proficiency levels and examples of иеs. [Електронний ресурс]. Доступно: https://ec.europa.eu/jrc/en/publication/eur-scientific-and-technical-research-reports/digcomp21-digital-competence-framework-citizens-eight-proficiency-levels-and-examples-use.

18. Christine Redecker, Yves Punie. "European Framework for the Digital Competence of Educators DigCompEdu". Luxembourg: Publications Office of the European Union, p. 93, 2017.

19. Ferrari A., "Digital Competence in Practice: An Analysis of Frameworks. Luxemburg: IPTS-JRC, 2011. [Електронний ресурс]. Доступно: http://ftp.jrc.es/EURdoc/JRC68116.pdf.

20. Martin A., Grudziecki J., " Concepts and Tools for Digital Literacy Development", Innovations in Teaching and Learning in Information and Computer Sciences, vol. 5, no. 4, 2006, pp. 246-264.

21. Scott " The Futures of Learning 3: What kind of pedagogies for the 21st century?". UNESCO Education Research and Foresight, Paris. [ERF Working Papers Series, no. 15]. [Електронний ресурс]. Доступно: http://unesdoc.unesco.org/images/0024/002431/243126e.pdf).

Матеріал надійшов до редакиіï 11.08.2018

\title{
РАЗВИТИЕ ЦИФРОВОЙ КОМПЕТЕНТНОСТИ ПЕДАГОГА В ИНФОРМАЦИОННО-ОБРАЗОВАТЕЛЬНОЙ СРЕДЕ УЧРЕЖДЕНИЯ ОБЩЕГО СРЕДНЕГО ОБРАЗОВАНИЯ
}

\author{
Карташова Любовь Андреевна \\ доктор педагогических наук, профессор, профессор \\ Коммунальное учебне заведение Киевского областного совета «Киевский областной институт \\ последипломного образования педагогических кадров», \\ Генеральный директор ООО «Акцент», г. Киев, Украина \\ lkartashova@ua.fm
}

\section{Бахмат Наталья Валерьевна}

доктор педагогических наук, доцент, профессор кафедры теории и методик начального образования Каменец-Подольский национальный университет имени Ивана Огиенко,

г. Каменец-Подольский, Украина

bahger.teacher@gmail.com

\section{Плиш Ирина Валерьевна}

кандидат педагогических наук, директор

Специализированная школа-детсад «Лесная сказка» с углубленным изучением иностранных языков,

г. Киев, Украина

apogey95@ukr.net

\begin{abstract}
Аннотация. Информатизация системы образования вызывает активное использование информационно-коммуникационных технологий (ИКТ) субъектами образовательного процесса, что положительно сказывается на его эффективности и способствует формированию профессиональных компетентностей педагогов. В работе выделяется одна из составляющих профессиональной компетентности, цифровая компетентность - качество педагога, означающее способность и умение систематического, логического и системного использования ИКТ, указывающее на его современность, мобильность и конкурентоспособность. Несмотря на разнообразие решений для ее развития, система образования Новой украинской школы требует поиска новых путей в этом направлении. Одним из них есть разработка инновационного электронного образовательного ресурса электронной платформы mobiSchool, которая является адаптированной к условиям непрерывной информатизации образования и содержит web-инструментарий для проектирования и формирования аутентичных электронных сред (web-прототипов)
\end{abstract}


учебных заведений. Экспериментальное внедрение mobiSchool указывает на положительные результаты в непрерывном повышении и развитии цифровых компетентностей педагогов. В основу разработки заложены принципы доступности, ясности, личностной направленности, формирования мотивации и заинтересованности. Указанный ресурс отличается от подобных тем, что он есть кроссплатформенным и не требует приобретения дополнительного оборудования; пользователи обеспечиваются тьюторским сопровождением; для работы пользователям достаточно получить от разработчика входные данные; пользователи получают различные уровни доступа (администратора, учителя, ученика, родителей); он является адаптивным - для каждого заведения образования разрабатывается его уникальный web-прототип; объединяет и реализует все функции образовательного процесса - обучающую, развивающую, воспитательную, стимулирующую (мотивационную) и организационную (управленческую), может быть использован для всех форм обучения.

Ключевые слова: электронный образовательный ресурс; информационно-образовательная электронная среда; Новая украинская школа; электронная платформа mobiSchool; электронный учебный кабинет; дистанционное обучение.

\title{
DEVELOPMENT OF TEACHER'S DIGITAL COMPETENCY IN TERMS OF INFORMATION AND EDUCATIONAL ENVIRONMENT OF A SECONDARY EDUCATION ESTABLISHMENT
}

\section{Lyubov A. Kartashova}

Doctor of Pedagogical Sciences, Professor, Professor of the Kyiv Regional Council

«Kyiv Regional Institute of Postgraduate Education in Teacher Training» Communal Educational Institution, General Director of Accent Ltd., Kyiv, Ukraine

lkartashova@ua.fm

\author{
Natalia V. Bakhmat \\ Doctor of Pedagogical Sciences, Associate Professor, Professor \\ Elementary Education Theory and Methods department of Kamyanets-Podilskyi Ivan Ogienko National \\ University, Kamyanets-Podilsky, Ukraine \\ bahger.teacher@gmail.com \\ Iryna V. Plish \\ PhD of Pedagogical Sciences, Director of the Specialized \\ Kindergarten «Forest Tale» with in-depth study of foreign languages, Kyiv, Ukraine \\ apogey95@ukr.net
}

\begin{abstract}
Informatization of the education system causes the active use of information and communication technologies (ICT) by the subjects of the educational process, which positively affects its effectiveness and promotes the formation of teacher's professional competency. One of the components of professional competency is the digital competency which means the teacher's ability of systematic, logical use of ICT, indicates its modernity, mobility and competitiveness. Despite the variety of solutions for its development, the education system of the New Ukrainian School needs to find the new ways in this direction. One of them is the development of an innovative e-learning resource - the e-platform mobiSchool, adapted to the conditions of continuous education informatization, and containing the web-tools for designing and creating the authentic electronic environments (web-prototypes) of educational institutions. Experimental implementation of mobiSchool points to positive results in the continuous improvement and development of teachers' digital competencies. The basis of the development is the principles of accessibility, intelligibility, personal orientation, the motivation and interest formation. The specified resource is different from the similar ones: it is a cross-platform that does not require the purchase of additional equipment; users are provided with tutorial support; it is enough for users to get input from the developer; users get different access levels (administrator, teacher, student, parents); it is adaptive - for each educational institution it develops its unique web-prototype; unites and implements all the functions of educational process - educational, developing, training, stimulating (motivational) and organizational (managerial); it can be used for all forms of learning.
\end{abstract}


Keywords: electronic educational resource; informational and educational electronic environment; New Ukrainian School; e-platform mobiSchool; e-learning office; distance learning.

\section{REFERENCES (TRANSLATED AND TRANSLITERATED)}

[1] V. Bykov, "Digital Competence of Teacher". [online]. Available: https://www.facebook.com/uesaccent/photos/pcb.1809058149395875/1809406686027688/?type=3. (in Ukrainian)

[2] V. Ju. Bykov, "Educational Environment of Modern Pedagogical Systems", Osvita Zaporizjkogho kraju. [Electronic resource]. [online]. Available: http://virtkafedra.ucoz.ua/el_gurnal/pages/vyp1/Bykov.pdf. (in Ukrainian)

[3] L. Gh. Ghavrilova Digital Culture, Digital Literacy, Digital Competence as Modern Educational Phenomena. [online]. Available: https://webcache.googleusercontent.com/search?q=cache:30SmhK8VVkQJ:https://journal.iitta.gov.ua/ind ex.php/itlt/article/download/1744/1243+\&cd=3\&hl=ru\&ct=clnk\&gl=ua. (in Ukrainian)

[4] L. Ghrynevych, "From the school where we pump knowledge, we turn to the school of competencies" [online]. Available: https://dt.ua/EDUCATION/liliya-grinevich-perehodimo-vid-shkoli-v-yakiy-tilkinapihayut-znannyami-ta-vidtvoryuyut-yih-do-shkoli-kompetentnostey-252819_html. (in Ukrainian)

[5] L. Ghrynevych, "Implementation of e-learning can take 5-7 years ". [online]. Available: https://day.kyiv.ua/uk/news/120218-vprovadzhennya-elektronnoyi-osvity-mozhe-zaynyaty-5-7-rokivgrynevych. (in Ukrainian)

[6] R.S. Ghurevych, "Informatization of Education - an Important Factor in the 21st Century Society Development", Suchasni informacijni tekhnologhiji ta innovacijni metodyky navchannja v pidghotovci fakhivciv : metodologhija, teorija, dosvid, problemy : Zb. nauk. pr., vyp. 47, pp. 5-10, 2016. (in Ukrainian)

[7] M. Ghurzhij, IT Readiness of Foreign Languages Teachers: Mmethodology, Theory, Technologies: Textbook/ Kyjiv: Instytut obdarovanoji dytyny, 2013. (in Ukrainian)

[8] State Standard of Basic and Complete Secondary Education (2011, lystop 23), Zakonodavstvo Ukrajiny/ [online]. Available: http://zakon2.rada.gov.ua/laws/show/1392-2011-\%D0\%BF. (in Ukrainian)

[9] Ju. O. Doroshenko, "Conceptual Principles of Forming the Informational Competence of Future Architects", Informacijno-komunikacijni tekhnologhiji v suchasnij osviti: dosvid, problemy, perspektyvy, pp. 133-139, 2012. (in Ukrainian)

[10] L. A. Kartashova, "Virtual School, Electronic Training Classes - not a Science Fiction, but a Ukrainian Reality". [online]. Available: http://knk.media/stati/1991-virtualna-shkola-elektronni-navchalni-klasi-nefantastika-a-ukrajinska-realnist.html). (in Ukrainian)

[11] L. A. Kartashova "Open Network Resource «Accent»: Innovative Opportunities for Educators", Komp'juter u shkoli ta sim'ji, №5 (133), pp. 3-8, 2016. (in Ukrainian)

[12] Concept of the new Ukrainian School [online]. Available: https://mon.gov.ua/storage/app/media/zagalna\%20serednya/nova-ukrainska-shkola-compressed.pdf. (in Ukrainian)

[13] I. Plish, "Distance Learning at School: Ukrainian Innovations Using " v sb. trudov KhI Mezhdunarodnoj nauchnoj konferencyy, Yzraylj. pp. 16-19, 2016.(in Ukrainian)

[14] Digital Agenda Project of Ukraine 2020 (Digital Agenda 2020) Conceptual framework (version 1.0). (Ghrud., 2016). [online]. Available: https://ucci.org.ua/uploads/files/58e78ee3c3922.pdf. (in Ukrainian)

[15] O. M. Spirin, "Information-communication and Informational Competencies as Components of the System of vocational-specialized Competences of Teacher of Computer Science", Informacijni tekhnologhiji $i$ zasoby navchannja, №5. 2009. [online]. Available: http://www.ime.eduua.net/em13/content/09somtio.htm. (in Ukrainian)

[16] K. Ala-Mutka, "Mapping Digital Competence: Towards a Conceptual Understanding. Luxemburg: IPTSJRC", 2011. [online]. Available: http://ipts.jrc.ec.europa.eu/publications/pub.cfm?id=4699. (in English)

[17] Carretero Gomez Stephanie, Vuorikari Riina, Punie Yves. "DigComp 2.1: The Digital Competence", Framework for Citizens with eight proficiency levels and examples of ues. [online]. Available:https://ec.europa.eu/jrc/en/publication/eur-scientific-and-technical-research-reports/ digcomp21-digital-competence-framework-citizens-eight-proficiency-levels-and-examples-use. (in English)

[18] Christine Redecker, Yves Punie. "European Framework for the Digital Competence of Educators DigCompEdu". Luxembourg: Publications Office of the European Union, p.93, 2017. (in English) 
[19] Ferrari A., "Digital Competence in Practice: An Analysis of Frameworks. Luxemburg: IPTS-JRC, 2011. [online]. Available: http://ftp.jrc.es/EURdoc/JRC68116.pdf. (in English)

[20] Martin A., Grudziecki J., " Concepts and Tools for Digital Literacy Development", Innovations in Teaching and Learning in Information and Computer Sciences, vol. 5, no. 4, pp. 246-264,2006. (in English)

[21] Scott, "The Futures of Learning 3: What kind of pedagogies for the 21st century?". UNESCO Education Research and Foresight, Paris. [ERF Working Papers Series, no. 15]. [online]. Available: http://unesdoc.unesco.org/images/0024/002431/243126e.pdf). (in English)

\section{(cc) BY-NC-SA}

This work is licensed under Creative Commons Attribution-NonCommercial-ShareAlike 4.0 International License. 